City University of New York (CUNY) CUNY Academic Works

\title{
A Flea's Tumescence: Alan Blum, MD, on Exhibitions, Activism, Irony, and Collaboration
}

David H. Lee

CUNY New York City College of Technology

\section{How does access to this work benefit you? Let us know!}

More information about this work at: https://academicworks.cuny.edu/ny_pubs/721

Discover additional works at: https://academicworks.cuny.edu

This work is made publicly available by the City University of New York (CUNY).

Contact: AcademicWorks@cuny.edu 


\title{
A Flea's Tumescence: Alan Blum, M.D. on Exhibitions, Activism, Irony and Collaboration
}

\author{
By David Lee
}

ABSTRACT: In November 2020, I spoke with Alan Blum, M.D., scholar, collector, curator, exhibitor, activist, and Director of the University of Alabama Center for the Study of Tobacco and Society (CSTS). He has been creating tobacco-themed exhibitions since the ' $80 \mathrm{~s}$ - in brick and mortar and digital settings — based on a prodigious collection of tobacco-related artifacts. Before CSTS, as founder of Doctors Ought to Care (DOC), a national organization of concerned and outspoken physicians, Blum satirized and protested at tobacco sponsored events. In addition to being an avid museumgoer he closely follows tobacco industry sponsorship of museums and exhibitions. This article contains excerpts from our interview, with Alan addressing the dynamism of tobacco marketing, the irony of CSTS exhibitions, his recollections of past exhibitions, and what he regards as the complicity of other industries and professions. Be advised that the exhibitions Blum curates and the views he expresses "may be hazardous to people's preconceptions."

KEYWORDS: University of Alabama Center for the Study of Tobacco and Society (CSTS); Alan Blum, M.D.; tobacco control; Doctors Ought to Care (DOC); public health

This is an account of my interview with Alan Blum, M.D., scholar, collector, curator, exhibitor, and activist, who directs the University of Alabama Center for the Study of Tobacco and Society (CSTS). Previously at Baylor College of Medicine in Houston, for the last 21 years Blum has been a family physician at the University of Alabama School of Medicine, Tuscaloosa. I first 
learned of his work after receiving the submission from Robert Riter and colleagues (this issue). Discovering CSTS exhibitions online (with artifacts such as hospital ashtrays; advertisements with infants promoting Marlboros; a program for a Virginia Slims benefit concert for The Foundation for AIDS Research (AmFAR); and a Chairman Mao cigarette lighter made in China that plays "The East is Red" when flicked) was a revelation, given my interest in exhibitions and health communication. We struck up a correspondence via email, and he agreed to be interviewed. We met for about two hours in November 2020 for a video chat which was recorded and transcribed. During the interview, I was given his "Surgeon General's warning" that the exhibitions he curates and the views he expresses "may be hazardous to people's preconceptions.”

The career of Alan Blum intersects with exhibitions in several ways relevant to the special issue. First, he has been creating tobacco-themed exhibitions since the ' $80 \mathrm{~s}$, both in museums and online. Second, Blum is the founder of Doctors Ought to Care (DOC), which shifted the focus of the anti-smoking movement to the tobacco industry by satirizing cigarette advertising and promotional events. Finally, he is an avid museumgoer and a close observer of exhibitions. Over the past 40 years, he has attended dozens of art exhibitions sponsored by Marlboro maker Philip Morris. The 2019 CSTS online exhibition, Museum Malignancy: Tobacco Industry Sponsorship of $\underline{\text { The Arts }}$ reflects his extensive documentation and earned him an invited commentary in The Art Newspaper.

In 1998 the major tobacco companies (Philip Morris, RJ Reynolds, Brown \& Williamson, and Lorillard) reached a multi-billion-dollar settlement with 46 state attorney generals (the "Master Settlement Agreement" or MSA). Money from the MSA has helped fund efforts in each state to reduce tobacco consumption. When the Food and Drug Administration was given regulatory control over tobacco products in 2009 , it funded the creation in academe of 14 "centers of excellence in tobacco regulatory science” at \$20 million apiece. In contrast, CSTS, which has never received 
funds from the MSA or the FDA, is supported by a handful of small donors, including Blum himself. During our interview I learned that he holds strong opinions not only about "Big Tobacco" but also other institutions that have collaborated with or enabled the tobacco industry. He is also critical of the "fear, foot-dragging, silo mentality, and lack of accountability" in the field known as "tobacco control."

The interview is heavily edited for inclusion here. Portions of the transcript were summarized and reworded for brevity. A complete transcript is available here. Although the range of topics we covered was broader, here I tried to include those parts most closely related to the topic of "exhibitions of impact." Removed were most mentions of tobacco industry sponsored sporting events; Blum's media mentor Tony Schwartz (creator of the fabled "Daisy Ad” for LBJ); Blum's acquaintance with nearly all US Surgeons General over the past half-century; and numerous other interesting asides and digressions. Quotes from Blum appear in blockquotes and, in my commentary, in quotation marks, unless stated otherwise.

\section{The Center for the Study of Tobacco and Society (CSTS)}

CSTS was founded in 1998 when Blum was named to the first endowed chair in family medicine in Alabama. On the establishment of CSTS:

Mrs. Celia Wallace very much wanted me to be the holder of the first Gerald Leon Wallace MD Endowed Chair in Family Medicine because her late husband, a dedicated family physician in Mobile, had passed away from smoking-related causes at a young age, as had my own father, Leon Blum, also a family physician.

Blum divides his time at the University of Alabama School of Medicine between seeing patients, 
teaching medical students and residents, and running CSTS. The main work product of the Center is online exhibitions, which are curated almost entirely from his vast collection of several hundred thousand items. Blum began collecting "cigarette advertising, tobacco industry reports, swag from annual shareholder meetings, and every kind of ephemera" over 40 years ago.

In 1977 my wife Doris was at a flea market in Coconut Grove and found a guy selling old TIME and LIFE magazines. We bought 400 of them, and it's really a great education, to look at the '30s, '40s and '50s through those eyes, because in almost every issue, the most advertised product was cigarettes, amid dozens upon dozens of ads.

His interest in tobacco marketing goes back to watching Brooklyn Dodgers games on TV with his father, who encouraged him to make audio recordings of the Lucky Strike commercials. "One day, no one will believe smoking and sports were associated," he remembers his dad saying.

A prized item in the CSTS collection is baseball-related: a kinescope, transferred to video, of "Happy Felton's Knothole Gang."

Happy Felton hosted the pre-game show for the Dodgers at Ebbets Field, and he would get three little leaguers to field and hit a couple of balls, usually with one of the Dodgers. The clip that I have is of Jackie Robinson throwing ground balls to them in the right field corner, directly in front of the Lucky Strike billboard. That just says it all. It's astonishing, and it probably would be the item that would stand in for all the collection.

Blum explains that almost every CSTS item has a story behind it. Irony is "the cornerstone of what we do." 
There are all sorts of deliberately-done ironies, such as the introduction by Phillip Morris CEO Hamish Maxwell in the late ' 80 s, in the catalogue for one the biggest exhibitions ever shown on Picasso and Braque at the Museum of Modern Art. The brief comment that Maxwell wrote (or was ghostwritten for him) concludes with his noting that Picasso and Braque took great risks, and "not taking risks is the greatest risk of all." Just perfect coming from the head of a cigarette company.

\section{Museum Malignancy}

The online exhibition Museum Malignancy (see description in previous chapter) documents the tobacco industry's sponsorship of art exhibitions and other cultural efforts. Blum traces tobacco sponsorship of the arts to the late sixties when the Fairness Doctrine required anti-smoking TV ads to balance the frequent cigarette commercials.

Those early anti-smoking ads by the American Cancer Society were so effective that cigarette smoking began leveling off, and the tobacco industry itself asked Congress to ban cigarette ads on TV--knowing that the anti-smoking messages would then also have to be pulled.

Meanwhile, cigarette makers came up with other ways to publicize their product. Phillip Morris VP George Weissman, who "prided himself on being a cultural maven," became a philanthropic fixture of the New York City art world, even rising to the presidency of Lincoln Center.

Weissman hit on the idea that using art might help burnish the company's image. Or in the 
words of a Philip Morris slogan he introduced, "It takes art to make a company great.” By the mid-seventies the company was sponsoring major museums, including the Metropolitan Museum of Art and the Whitney Museum of American Art. It even created a branch of the Whitney in Philip Morris headquarters across from Grand Central Station. I would visit it regularly to collect the exhibition pamphlets. They got a lot of visitors because the lobby had public benches and a newsstand. One time I noticed a group of sixth graders touring the small gallery and the teacher gave me permission to ask them a question. "Kids," I said, “what does Philip Morris make?” and one little girl exclaimed, "I know! Paintings!”

According to Blum, by the early 1990s Philip Morris had "morphed into almost any identity it wanted to present at a given moment." One of the many PM-sponsored exhibitions featured in Museum Malignancy is The Vatican Collections: The Papacy and Art at the Met. The New York Times covered the "house call" that Blum and other DOC members staged in front of the Met in February 1983.

\section{A Form of Flattery}

Also featured in Museum Malignancy is evidence of Blum's first-ever curated exhibition in 1988 called When 'More Doctors Smoked Camels': A century of health claims in tobacco advertising, 1888 to 1988. On view at the Texas Medical Center Library in Houston, it featured 80 items from Blum's growing collection of tobacco advertising with commentary about health claims made in cigarette ads throughout the $20^{\text {th }}$ century. The exhibition was created to coincide with the First National Conference on Tobacco Use in America (at which Blum was a keynote speaker) held at the nearby MD Anderson Cancer Center. In 2019, over thirty years later, to his disbelief, a "virtually identical" exhibition with the title More Doctors Smoke Camels opened at the 
Smithsonian Institution National Museum of American History.

This led me to create Museum Malignancy [designed by CSTS digital archivist Kevin Bailey] and to include a section called "Carbon Copy?" where I posted the link to the Smithsonian's exhibit as well as the key to my more in-depth exhibition from 1988. I also included photographs of me at both places [see appendices]. The ultimate irony is that the Smithsonian still takes money from Philip Morris--to the present day.

Blum's original exhibition was not credited by the Smithsonian in its 2019 version. The "Carbon Copy?" exhibit webpage shows that exhibitions don't have the same copyright protections as articles and other forms of intellectual property. "Carbon Copy?" features a 1993 article from the journal College \& Research Libraries called "Exhibits: Illegitimate Children of Academic Libraries?" in which authors Laurel Bowen and Peter Roberts make the case that original exhibitions are the equal of scholarly articles.

Blum hopes that, through online exhibitions, more people can be reached than would be by a scholarly article or book. "In the internet era, I want to make the exhibitions as widely available as possible and make the content as accessible as possible."

\section{Doctors Ought to Care (DOC)}

Recounting some memorable moments of DOC's history provides insight into the activist origins of CSTS. In the '70s, as a resident in family medicine at Jackson Memorial Hospital of the University of Miami School of Medicine, Blum began presenting talks at public schools in low income, predominantly African American neighborhoods on smoking and other issues. 
That led to other doctors joining me, and we started a group called DOC. We tried counteracting the promotion of cigarettes through demonstrations in white coats ["house calls"] at tobacco-sponsored events such as the Benson \& Hedges Film Festival, which debuted at a theater across from the University of Miami in September 1977. We renamed it the Benson \& Heart Attack Film Festival. We started taking out paid ads in newspapers. To parody the first movie of the Benson \& Hedges Film Festival, which was "A Streetcar Named Desire,” our ad said, “A Streetcar Named Emphysema.” We bought bus benches throughout Miami saying, "Country Fresh Arsenic" and "Full-Bodied Cyanide," which we'd place opposite cigarette billboards. We received our first national attention for these.

DOC would eventually expand to more than 80 chapters in medical schools all over the country. Although several DOC chapters remain, the national office closed in 2002 when "pretty much every other organization had co-opted all our best ideas. But we left a legacy of humor, satire, and 'laughing the pushers out of town."'

In 1989, Phillip Morris “paid the National Archives to send around the Bill of Rights in a Brinks' truck" and sponsored an essay contest, with cash prizes, about freedom of speech and 'What the Bill of Rights means to me.'

So DOC promoted an essay contest of our own for law students, with a full page ad in The Nation magazine, to answer the question, "Should tobacco company executives be held criminally liable for the deaths, diseases, and fires that their products cause?"...We also made fun of the tour by creating an 8-foot-tall replica of the Statue of Liberty in chains and holding up a pack of Virginia Slims: The Statue of Nicotina. We dogged them through many states with Nicotina, and Philip Morris called off the tour early. 
In their journey, DOC advocates found themselves shoulder to shoulder with other historic activist groups. For example:

In the early-1990s in Houston, we went to protest the Marlboro Country Music Festival sponsored by Philip Morris. As we were unfurling our posters and signs like "Come to Barfboro Country" and "Philip Morris destroys healthy bodies 12 ways" [a parody of the old Wonder Bread slogan], we saw another group of protesters. It's the first time I've ever gone to a protest and had people beat me there. "Who are you?" I asked. "We're ACT UP," the leader said. They were protesting the homophobia of Jesse Helms, who was Philip Morris' biggest backer in Congress, and we were fighting Philip Morris. So, we united that night and protested together.

\section{SLAPP Suit}

In 1988, DOC heard that Miller Beer (owned by Philip Morris) was going to come to Houston to hold the "world's largest party" at the Astrodome. The heavily promoted event (to be headlined by The Who, and featuring TV ads with Randy Quaid), had the tagline "Miller Lite Beer. We're having a party!” DOC commissioned artist Doug Minkler to depict a guy throwing up into a toilet, with the tagline, "Killer Lite Beer. We're grabbing a potty!"

On the back of the shirt, we had a fetus and a list of diseases that alcohol can cause, including fetal alcohol syndrome. The topper was that the beneficiary of the Miller Lite event was, believe it or not, the Special Olympics. 
Although satire is a protected form of protest, DOC became the target of a SLAPP suit (Stop Legal Access to Public Participation) intended to burden them with a costly legal defense. The Houston affiliate of the American Civil Liberties Union (ACLU) agreed to take the case.

It was a six-month stress headache, but we prevailed: we agreed to abide by the First Amendment! It's just an example of the lengths the tobacco industry will go to. Thomas More said, "The devil can't stand to be mocked." ...The tobacco companies love to be called Merchants of Death, but they don't like being made fun of. They don't like seeing DOC's Emphysema Slims or our Barfboro Man or anything that makes fun of their brand names.

\section{Other Exhibitions}

I was curious if Blum could name other exhibitions that had an impact on him. He immediately mentioned a 2001 exhibition on eugenics at the International Center for Photography:

It took up only a single room but was absolutely the best, most shocking and revelatory exhibition I can ever recall seeing--how Harvard leaders, state government officials, and all sorts of people you'd never expect were really the early supporters of eugenics, some of whom ordered sterilizations so that various groups of people couldn't reproduce. This is believed to have led to euthanasia and then to the Holocaust.

He also cites the New-York Historical Society's two-part exhibition Slavery in New York (2005 and 2011). About Hope and Healing: Painting in Italy in a Time of Plague 1500-1800 (2005) at the Worcester Museum of Art: 
These were mostly paintings of saints. I had no idea who they were, but I felt like an illiterate peasant might have in the 16th century looking up at these paintings to gain comfort. I'm Jewish, but this was the most inspiring and moving exhibition I can ever recall.

At the Imperial War Museum in London, Blum experienced his "single most moving moment" ever in a museum. "In one darkened room, there was a lone spotlight on a glass case, which contained only one item--a glass syringe from Auschwitz, where Mengele had done his sadistic medical experiments."

\section{On "Big Tobacco" and "Tobacco Control"}

Blum states that CSTS were leaders in uncovering the machinations of the tobacco industry:

We were the first anti-smoking organization to get access to tobacco industry documents, and my colleague [DOC's executive director] Eric Solberg was the first person to catalogue them and make them available to the Food and Drug Administration when it originally tried to regulate tobacco products in the 1990s.

During our interview, I learned Blum is uncomfortable with the term "Big Tobacco" because he associates it with large settlements obtained by plaintiff lawyers in the 1990s, who did "some good and some bad on this issue."

Some of [the lawyers] used the opportunity to run for governor, but most of that money has gone toward general revenue. Very little has gone for what the attorneys general initially said it would go for, which was to pay for the cost of the healthcare of all the people made ill 
by smoking.

In 2002 the library of the University of California San Francisco received \$15 million from the MSA-funded American Legacy Foundation to create the online Legacy Tobacco Industry Documents archive (now called Truth Tobacco Industry Documents https://www.industrydocuments.ucsf.edu/tobacco/), featuring millions of digitized tobacco industry documents released under the MSA and other lawsuits. To Blum, the quality of research based on these documents varies greatly.

[Most people in tobacco control] assume it [anti-smoking activism] all began when the state attorneys general sued the tobacco industry, and that's just nonsense. There was Carrie Nation in the 1890s fighting against smoking, among many others. Cigarette sales were even banned in several states in the early $20^{\text {th }}$ century. The first lecture at a medical school in the United States against smoking that I know of --a copy of which is one of the rarest items in my collection--was given to the graduating class of Harvard Medical School in 1804 by Dr. Benjamin Waterhouse (who had popularized vaccination in America)... So, people today are way behind the curve. The first time the U.S. paid money out of the taxpayers' pocket [to purchase mass media space] to encourage people to stop smoking was in 2012. That was 35 years after I bought $\$ 3,000$ worth of bus benches all over Miami [with satirical anti-smoking messages].

Blum is especially proud of how CSTS online exhibitions compare to the websites of far betterfunded tobacco control organizations: 
...if this was just about Big Tobacco, you could open up any website from the Johns

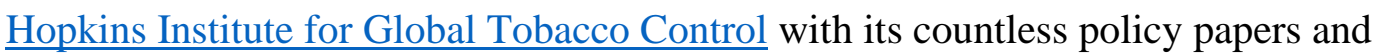
presentations, to the UCSF internal tobacco industry documents and read about Big Bad Tobacco forever. If you want to read about what some middle manager dreamed of in the 1960s, go right ahead, it's endlessly fascinating stuff. But what I kept from being thrown away [and hopefully what we will keep preserving in climate-controlled storage for $\$ 20,000$ a year] is what the industry and its allies actually did. The Hopkins Institute has received $\$ 300$ million. We have an annual budget closer to $\$ 80,000$. I saved everything the industry actually did, which I think matters more than what somebody might claim the industry thought of doing.

He claims that while others may provide interesting statistics and policy papers, they don't stack up to CSTS's exhibitions in educational value for students from middle school to medical school and for health professionals and the general public alike.

I'll put any of my items and its provenance up against any tobacco industry document... I don't begrudge people who use them [the tobacco industry documents]. I just think they can lead to a kind of hemianopsia, which is the medical term for when you only see out of one part of your eye.

He characterizes the overall narrative of tobacco control as misleading:

Every field, I'm sure, has a single narrative, and the tobacco control single narrative is that we're David and we beat Goliath. It's about as untrue an analogy as you can make. We stopped being David in the 1990s when we started getting tens of millions of dollars to fight 
Big Tobacco, and... instead of making a really good slingshot, we made really good meetings at which we could share our research.

Blum alludes to the fact that the tobacco industry remains profitable and its addictive products are still readily available:

An analogy would be if you see someone who is being confronted by a thug with a gun, you would normally try to take down the guy with the gun. The tobacco control approach is to hold up a sign to the person being victimized and say, "Hey watch out, that gun could hurt you." Or you go up to the person holding the gun and say, "Please don't do that."

\section{Collaborationism}

Blum says that if he had to describe his activities in a word, it would be a toss-up between "irony" for the content of exhibitions and "collaboration" for the overall description of industries and institutions that enabled the tobacco industry, including organized medicine, media corporations, and arts organizations.

I'm not into looking at either victims or perpetrators as much as I am collaborators.

Collaboration is what I call a two-headed word--one that has opposite meanings.

"Collaborate" to me is supposed to be a wonderful thing. I love collaborating with colleagues on an article or an exhibition, for instance. But I can't think of the word collaboration without thinking of Vichy. France didn't even acknowledge its collaboration for the better part of 50 years. As the author Brian Moore said in an interview on NPR, paraphrasing a deathbed comment by Charles de Gaulle, "His greatest gift to the French people was to convince them that they'd been an occupied country." 
One CSTS exhibition from 2014 is entitled The Surgeon General vs. The Marlboro man: Who Really Won? This is the question I posed to Alan, who answered, without hesitation, "The tobacco industry, no question about it."

They've always been the most dynamic industry because they have to be. If they showed what smoking really caused (and if people stood up to them), they'd be out of business. But nobody in the media, which coveted their advertising dollars; nobody in academia, which sought their research dollars; nobody in the financial sector, which of course helped them every step of the way; and nobody in the pharmaceutical industry, which helped make many of the same chemicals for tobacco manufacturers, ever lifted a finger to fight the tobacco industry. Hospital executives were silent. Medical associations were silent. In fact, they collaborated with the tobacco industry in the '60s to try to prevent Medicare from being passed by Congress. It's a very dark story. It's a tragedy. There are few heroes. This is not the triumph that the public health community likes to pretend it is.

Blum sees the promotion of cigarettes as a metaphor for other unhealthy products and lethal lifestyles, such as tanning beds, junk food, alcohol, cellphones, and social media platforms--all subjects of original CSTS presentations and research posters.

We're a resource that few know about. Usually people find us last when they can't find it anywhere else. We're the only resource that looks not just at the tobacco industry but also its allies...We take no prisoners in that we also look at the other side, the tobacco control community--those who make their living off "fighting Big Tobacco," and we show that 
there has been rather slow progress over the 50 years that we've known what smoking does to you, proportionate to the money going into this field.

Blum's career, starting with DOC, shows how exhibitions are the outgrowth of a media activism that included paid print advertisements, billboards, graffiti, and other "guerilla" communications in service of anti-corporate public health activism. His mordant sense of humor is also capable of reflexively mocking his own acute sense of indignation. I asked Alan if he would be writing a memoir. He replied that if he did, the title would be "The Flea with an Erection" after a wisecrack made in 1990 by an unimpressed executive from ABC Films. Alan had been invited to pitch an educational film based on his popular anti-smoking talks at high schools and junior highs. After giving his "Bart Simpson-like" presentation to a roomful of executives,

...their mouths just dropped open. One of them said, "You really think that this is what's going to make kids not smoke? Where are all the pictures of the cancerous lungs and grungy mouths?" I said “That's just not what works. Laughing the pushers out of town is what gets them thinking about it." Another guy got so angry he said, "You know what you remind me of? You're like the flea with an erection floatin' down the Hudson River yellin' 'Open the bridge! Open the bridge!" 


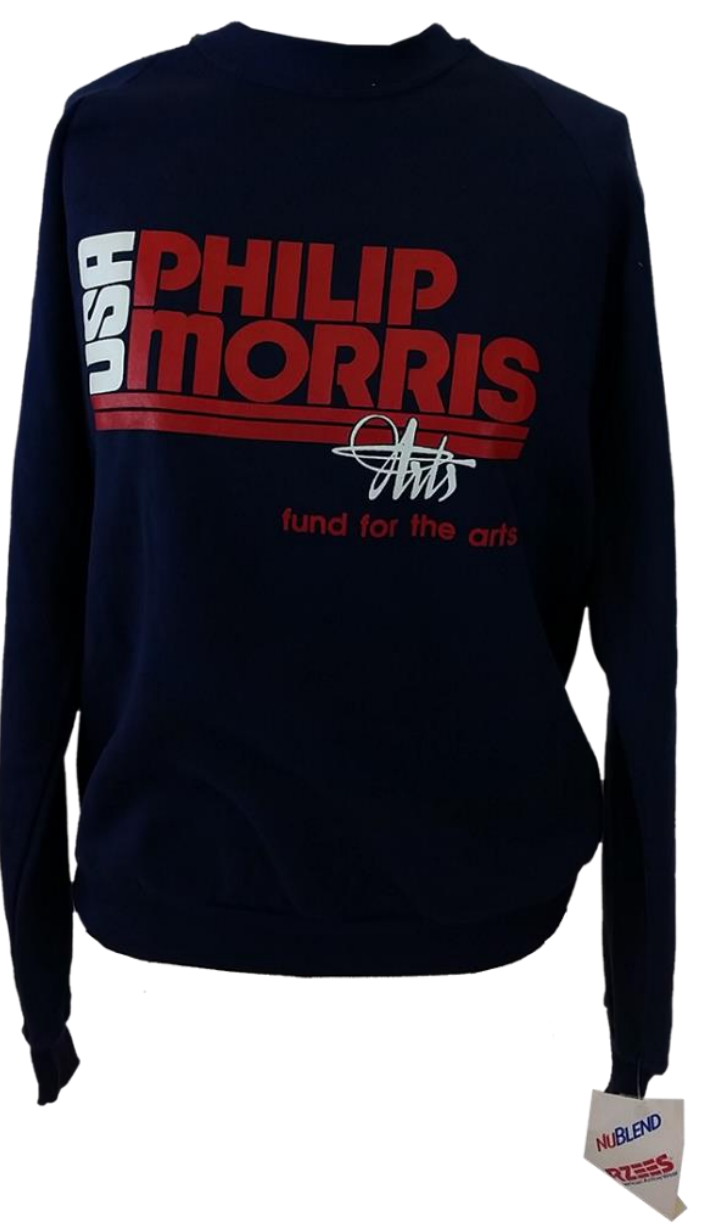

Phillip Morris Fund for the Arts Sweatshirt (1990)

https://csts.ua.edu/files/2019/05/1990-Phillip-Morris-USA-Philip-Morris-Fund-for-the-Arts-2658x1030.png 


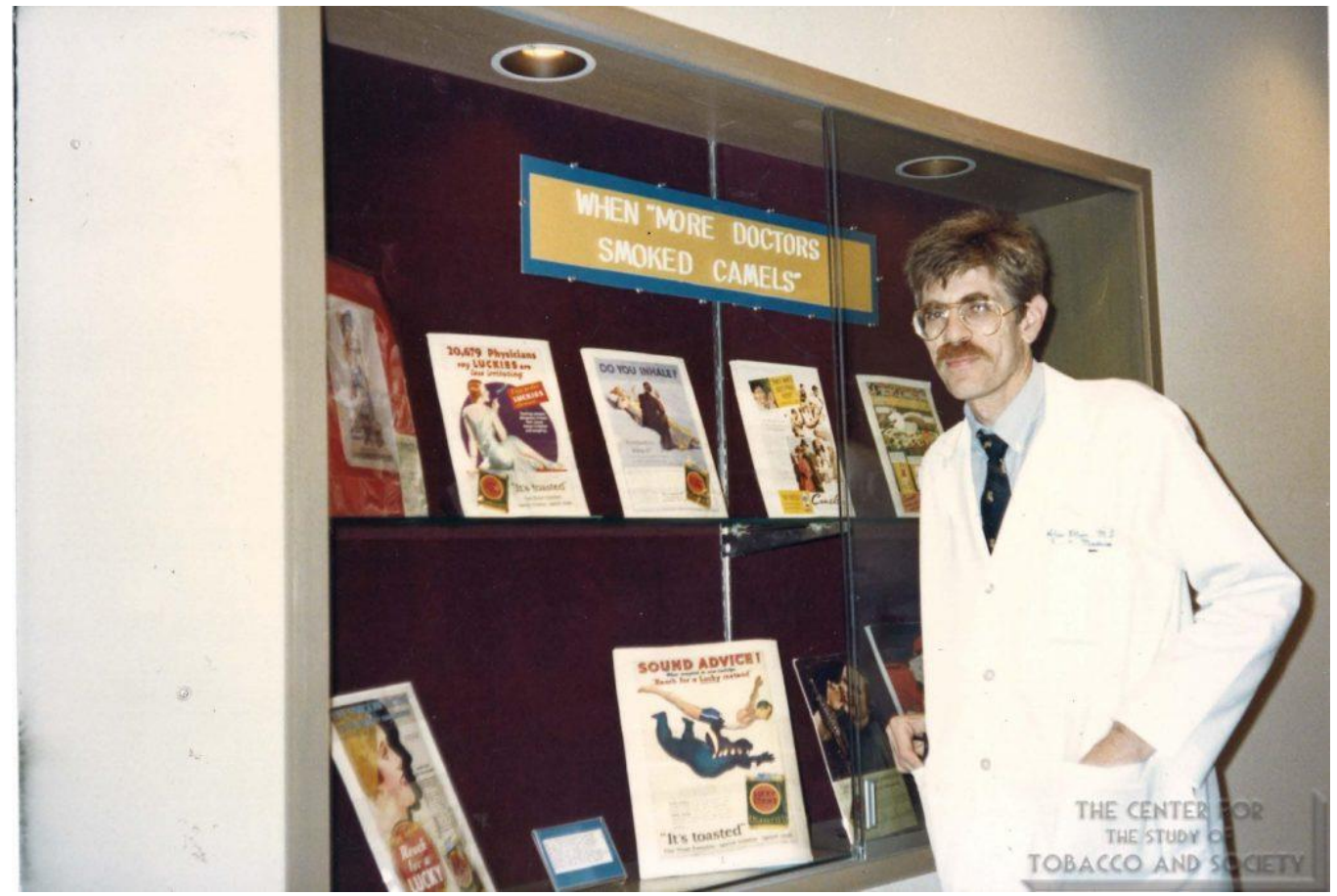

Blum at the original "When More Doctors Smoked Camels" exhibition, 1988

https://csts.ua.edu/files/2019/06/1988-Alan-Blum-Photo-of-When-More-Doctors-Smoked-CamelsExhibition-1030x692.jpg 


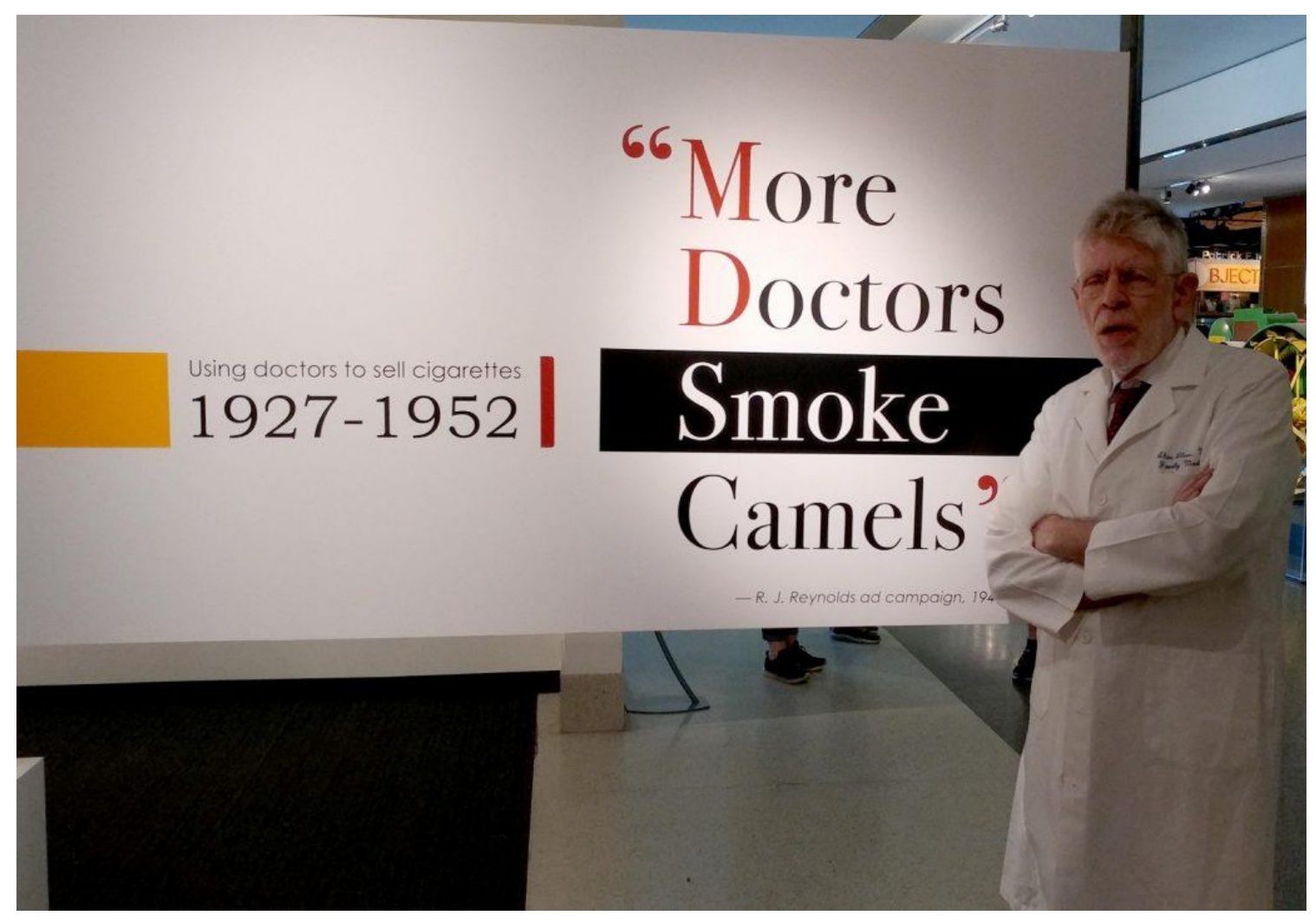

Blum at the Smithsonian “carbon copy” exhibition, 2019 https://csts.ua.edu/files/2019/06/2019-ABat-Smithsonian-When-More-Doctors-Smoked-Camels-Exhibition-1030x716.jpg 